\title{
Effect of Magnesium as Substitute Material in Enzyme-Mediated Calcite Precipitation for Soil-Improvement Technique
}

\author{
Heriansyah Putra ${ }^{1,2 *}$, Hideaki Yasuhara ${ }^{3}$, Naoki Kinoshita ${ }^{3}$, Debendra Neupane ${ }^{4}$ and \\ Chih-Wei Lu ${ }^{5 *}$ \\ ${ }^{1}$ Disaster Mitigation for Asian Students, Graduate School of Science and Engineering, Ehime University, Matsuyama, Japan, \\ ${ }^{2}$ Engineering Faculty, Jambi University, Jambi, Indonesia, ${ }^{3}$ Department of Civil and Environmental Engineering, Ehime \\ University, Matsuyama, Japan, ${ }^{4}$ Penta - Ocean Construction Co. Ltd, Tokyo, Japan, ${ }^{5}$ Department of Construction \\ Engineering, National Kaohsiung First University of Technology, Kaohsiung, Taiwan
}

OPEN ACCESS

Edited by:

Varenyam Achal,

East China Normal University, China

Reviewed by: Jose M. Bruno-Barcena, North Carolina State University, USA Zeynep Basaran Bundur.

Ozyegin University, Turkey

*Correspondence: Heriansyah Putra putra.heriansyah@cee.ehime-u.ac.jp; Chih-Wei Lu cwlu@nkfust.edu.tw

Specialty section: This article was submitted to Microbiotechnology, Ecotoxicology and Bioremediation, a section of the journal Frontiers in Bioengineering and Biotechnology

Received: 14 January 2016 Accepted: 18 April 2016 Published: 04 May 2016

Citation:

Putra H, Yasuhara H, Kinoshita N, Neupane D and Lu C-W (2016) Effect of Magnesium as Substitute

Material in Enzyme-Mediated Calcite Precipitation for Soil-Improvement Technique. Front. Bioeng. Biotechnol. 4:37. doi: 10.3389/fbioe.2016.00037
The optimization of enzyme-mediated calcite precipitation was evaluated as a soilimprovement technique. In our previous works, purified urease was utilized to biocatalyze the hydrolysis of urea, which causes the supplied $\mathrm{Ca}^{2+}$ to precipitate with $\mathrm{CO}_{3}^{2-}$ as calcium carbonate. In the present work, magnesium chloride was newly added to the injecting solutions to delay the reaction rate and to enhance the amount of carbonate precipitation. Soil specimens were prepared in PVC cylinders and treated with concentration-controlled solutions composed of urea, urease, calcium, and magnesium chloride. The mechanical properties of the treated soil specimens were examined through unconfined compressive strength (UCS) tests. A precipitation ratio of the carbonate up to $90 \%$ of the maximum theoretical precipitation was achieved by adding a small amount of magnesium chloride. Adding magnesium chloride as a delaying agent was indeed found to reduce the reaction rate of the precipitation, which may increase the volume of the treated soil if used in real fields because of the slower precipitation rate and the resulting higher injectivity. A mineralogical analysis revealed that magnesium chloride decreases the crystal size of the precipitated materials and that another carbonate of aragonite is newly formed. Mechanical test results indicated that carbonate precipitates within the soils and brings about a significant improvement in strength. A maximum UCS of 0.6 MPa was obtained from the treated samples.

Keywords: EMCP, carbonate, magnesium chloride, delaying agent, soil improvement

\section{INTRODUCTION}

Bio-chemical grouting, as a ground-improvement method, has been studied for its various possible applications, such as the preservation of limestone monuments (Al-Thawadi, 2011), the plugging up of the pores in oil recovery reservoir rocks and the removal of contaminants in groundwater systems (Nemati et al., 2005), the reparation of cracks in concrete (De Muynck et al., 2008), the reduction of the swelling potential of clayey soil and the mitigation of the liquefaction potential of soil (Ivanov and Chu, 2008; Akiyama and Kawasaki, 2012; Putra et al., 2015), and the control of and the improvement in the soil permeability (Whiffin et al., 2007; van Paassen et al., 2009; DeJong et al., 2010; Harkes et al., 2010; Yasuhara et al., 2012). Thus far, most studies on enzymatic calcite grouting have used bacterial 
cells containing urease, e.g., Sporosarcina pasteurii, to dissociate urea into ammonium and carbonate ions (Whiffin, 2004; DeJong et al., 2006; Whiffin et al., 2007; van Paassen et al., 2010).

Microbially induced calcite precipitation (MICP) may be one of the promising bio-mediated soil-improvement techniques (DeJong et al., 2011; Martinez et al., 2013). MICP has been studied extensively for its potential as a novel soil-improvement technique. The increase in compressive strength ranges from 0.2 to $12 \mathrm{MPa}$ depending on the amount of precipitated calcite (van Paassen et al., 2010).

Enzyme-mediated calcite precipitation (EMCP) (Yasuhara et al., 2011, 2012; Neupane et al., 2013) may be an alternative method for improving soil properties. An enzyme reagent mixed solution (i.e., $\mathrm{CaCl}_{2}$-urea-urease solution), which produces the precipitated calcite after the chemical reaction, is injected into the soil. The precipitated calcite may provide bridges between the grains of sand, restricting their movement, and hence, improving the stiffness and the strength of the soil (Yasuhara et al., 2011). For instance, the efficacy of 1-2 g/L of the enzyme with the activity of $2950 \mathrm{U} / \mathrm{g}$ was evaluated in our previous works (Neupane et al., 2013; Putra et al., 2015). A precipitation ratio of calcite of up to $70 \%$ was obtained using a small amount of a urease and reagent solution. The amount of precipitated calcite varied from 1.5 to $6.0 \%$ of the sand weight on the inner spherical portion, with a diameter of $30 \mathrm{~cm}$, and the corresponding reduction in porosity ranged from 2 to $7 \%$. The amount of precipitated calcite may be enough to modify the mechanical properties of sandy soil (Neupane et al., 2013). The treated sand displays sufficient strength as a grouting material to counteract soil liquefaction (Putra et al., 2015). However, the uniform distribution of calcite within a large domain has not yet been achieved. The precipitation rate may have a remarkable influence on the treatment area (Neupane et al., 2015).

A study on the carbonation rates of calcite has been reported by Apriliani et al. (2012). It was concluded in their study that the addition of magnesium to the inorganic carbonation process delayed the carbonate precipitation rate, modified the structure and the size of the precipitated crystals, and generated dolomite and magnesium carbonate (Apriliani et al., 2012). The concentration of $\mathrm{Mg}^{2+}$ ions influenced the morphology of the $\mathrm{CaCO}_{3}$ polymorphs, and the precipitated calcite was seen to possibly progress from angular to spherical as the $\mathrm{Mg}^{2+}$ ions increased (Boyd, 2012). The carbonation process described in the previous works was investigated inorganically, but it may also be examined in organic processes, such as MICP and EMCP.

In this work, various amounts of magnesium were used to examine the rate and the magnitude of carbonate precipitation when added to grouting materials, i.e., $\mathrm{CaCl}_{2}$-urea-urease solution (Yasuhara et al., 2011, 2012; Neupane et al., 2013, 2015). Moreover, the effects of the added magnesium exerted on the size and the structure of the precipitated crystals and the formation of other carbonate minerals (e.g., dolomite, magnesite, and aragonite) were also evaluated. The optimal combination of reagents was fixed by test-tube tests and then utilized to improve small-scale specimens. The microstructures of the precipitated carbonates were examined by X-ray powder diffraction (XRD) and scanning electron microscopy (SEM) to assess the effects of magnesium on the formation of carbonates. Unconfined compressive strength (UCS) tests were also performed to evaluate the improved mechanical properties of the treated specimens by the presence of the magnesium. Finally, by comparing the relation between the UCS and the amount of carbonate precipitated within the treated specimens obtained in this work, with those obtained from the literature, the influence of the added magnesium was explicitly investigated.

\section{MATERIALS AND METHODS}

\section{Materials}

Urea, $\mathrm{CaCl}_{2}$, and $\mathrm{MgCl}_{2}$, with claimed purity levels $>95.0 \%$, were obtained from Kanto Chemicals Co. Inc. Urease (020-83242, Kishida Chemical, Osaka, Japan), purified from jack bean meal and with urease activity of $2950 \mathrm{U} / \mathrm{g}$, was used in the bio-catalytic dissociation of urea. Poorly graded silica sand \#6 with $\mathrm{e}_{\max }, \mathrm{e}_{\min }$, $\mathrm{C}_{\mathrm{u}}$, and specific gravities of $0.899,0.549,1.55$, and 2.653 , respectively, was used in this work. The grain size distribution curve of the sand utilized in this work is shown in Figure $\mathbf{1}$.

The expected reactions to obtain precipitated carbonate ions in the presence of calcium ions $\left(\mathrm{Ca}^{2+}\right)$ and magnesium ions $\left(\mathrm{Mg}^{2+}\right)$ supplied in the solution are shown in Eqs. 1-5.

$$
\begin{gathered}
\mathrm{CO}\left(\mathrm{NH}_{2}\right)_{2}+2 \mathrm{H}_{2} \mathrm{O} \rightarrow 2 \mathrm{NH}_{4}^{+}+\mathrm{CO}_{3}^{2-} \\
\mathrm{CaCl}_{2} \rightarrow \mathrm{Ca}_{2}^{+}+2 \mathrm{Cl}^{-} \\
\mathrm{MgCl}_{2} \rightarrow \mathrm{Mg}_{2}^{+}+2 \mathrm{Cl}^{-} \\
\mathrm{Ca}_{2}^{+}+\mathrm{CO}_{3}^{2-} \rightarrow \mathrm{CaCO}_{3} \\
\mathrm{Mg}_{2}^{+}+\mathrm{CO}_{3}^{2-} \rightarrow \mathrm{MgCO}_{3}
\end{gathered}
$$

\section{Test-Tube Experiments}

In this work, the precipitation of carbonate was evaluated directly in transparent test tubes. The magnesium was substituted in the

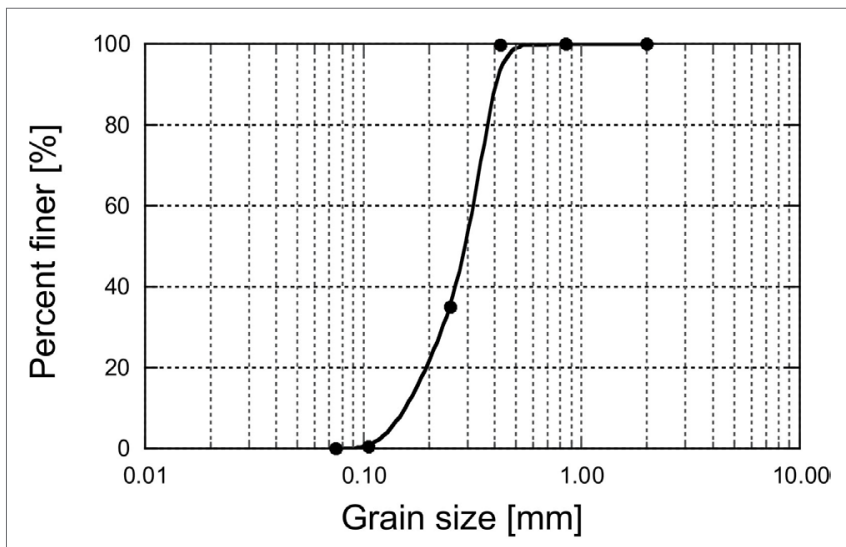

FIGURE 1 | Grain size distribution curve of sand. 
$\mathrm{CaCl}_{2}$-urea solutions whose concentrations varied from 10 to $50 \%$ of the initial concentration of $\mathrm{CaCl}_{2}$ (i.e., $0.5 \mathrm{~mol} / \mathrm{L}$ ). The total concentration of $\mathrm{CaCl}_{2}-\mathrm{MgCl}_{2}$ was fixed at $0.5 \mathrm{~mol} / \mathrm{L}$. One gram per liter of urease was used to dissociate $0.5 \mathrm{~mol} / \mathrm{L}$ of urea. The experimental conditions for the precipitation tests are listed in Table 1. Urease powder was mixed with distilled water, stirred for $2 \mathrm{~min}$, and then filtered using filter paper (pore size of $11 \mu \mathrm{m}$ ) to remove the undissolved particles. Combinations of $\mathrm{CaCl}_{2}-$ $\mathrm{MgCl}_{2}$-urea and the purified urease were mixed thoroughly to make a total solution volume of $30 \mathrm{~mL}$ and allowed to react until the system reached the steady state. During the entire 6-day curing time, the test tubes were kept in a box without shaking. Note that the solutions were always mixed and the samples were always cured at a room temperature of $20^{\circ} \mathrm{C}$. After $24 \mathrm{~h}$, the solutions were filtered through the filter paper (pore size of $11 \mu \mathrm{m}$ ). The particles deposited on the filter paper and the particles remaining in the tubes were dried at $60^{\circ} \mathrm{C}$ for $24 \mathrm{~h}$, and the total amount of precipitated materials was evaluated by combining the precipitated materials deposited in the test tubes with the materials remaining on the filter paper. The precipitation ratio, which is the ratio of the actual mass of the precipitated materials to the theoretical mass of the maximum precipitation of $\mathrm{CaCO}_{3}$, was obtained. The theoretical mass of $\mathrm{CaCO}_{3}(\mathrm{~g})$ was evaluated as $C \cdot V \cdot M$, where $C$ and $V$ represent the concentration of the solution in moles per liter and the volume of the solution in liters, respectively, and $M$ is the molar mass of $\mathrm{CaCO}_{3}$ of $100.087 \mathrm{~g} / \mathrm{mol}$. The actual mass is the mass of the precipitated materials in grams evaluated from the tests. The evaluation of the precipitated mass was conducted every $24 \mathrm{~h}$ until the system reached the steady state. Two identical tests were performed for each condition to check the reproducibility.

Test-tube experiments were conducted to examine the effect of magnesium on the rate of urea hydrolysis in the presence of urease. The measurement of the evolution of $\mathrm{pH}$ with time might

\begin{tabular}{|c|c|c|c|c|}
\hline \multirow{2}{*}{$\begin{array}{l}\text { Sample } \\
\text { case }\end{array}$} & \multicolumn{2}{|c|}{ Concentration of $\mathrm{CaCl}_{2}$} & \multicolumn{2}{|c|}{ Concentration of $\mathrm{MgCl}_{2}$} \\
\hline & Ratio (\%) & $(\mathrm{mol} / \mathrm{L})$ & Ratio (\%) & (mol/L) \\
\hline $\mathrm{CO}$ & 100 & 0.50 & 0 & 0.00 \\
\hline $\mathrm{C} 1$ & 90 & 0.45 & 10 & 0.05 \\
\hline C2 & 80 & 0.40 & 20 & 0.10 \\
\hline C3 & 70 & 0.35 & 30 & 0.15 \\
\hline $\mathrm{C} 4$ & 60 & 0.30 & 40 & 0.20 \\
\hline C5 & 50 & 0.25 & 50 & 0.25 \\
\hline
\end{tabular}

TABLE 2 | Experimental conditions for PVC cylinder tests.

\begin{tabular}{lccc}
\hline \multirow{2}{*}{$\begin{array}{l}\text { Sample } \\
\text { case (-) }\end{array}$} & $\begin{array}{c}\text { Number of pore } \\
\text { volumes (times) }\end{array}$ & \multicolumn{2}{c}{ Maximum precipitated } \\
\cline { 3 - 4 } & & Mass (g) & Ratio (\%) \\
\hline U1 & 1 & 3.75 & 1.25 \\
U2 & 2 & 7.50 & 2.50 \\
U3 & 3 & 11.25 & 3.75 \\
U4 & 4 & 15.00 & 5.00 \\
U6 & 6 & 22.50 & 7.50 \\
U8 & 8 & 30.00 & 10.00 \\
\hline
\end{tabular}

${ }^{a}$ Calcite content in $300 \mathrm{~g}$ of treated sand. indirectly define the rates and the magnitude of urea dissociation accelerated by the urease (Yasuhara et al., 2012). The evolving $\mathrm{pH}$ was measured using a $\mathrm{pH}$ meter $0,1,2,3,6,7,8,9$, and $10 \mathrm{~h}$ after mixing. The amount and the characteristics of the precipitated materials obtained from the test-tube experiments, corresponding to the different ratios of $\mathrm{CaCl}_{2}-\mathrm{MgCl}_{2}$, were also evaluated in this work. XRD and SEM analyses of the precipitated carbonate were conducted to analyze and to examine the mineralogical substances.

\section{Unconfined Compressive Tests}

Unconfined compressive strength tests were carried out to evaluate the improvement in stiffness and strength of the treated sand specimens. PVC cylinders ( $5 \mathrm{~cm}$ in diameter and $10 \mathrm{~cm}$ in height) were used to prepare the sand samples. The fixed volume of the solution was injected into each prepared sand specimen. The injected volume was controlled by the number of pore volumes, one pore volume being $\sim 75 \mathrm{~mL}$. The experimental conditions for the PVC cylinder tests are listed in Table 2.

First, $300 \mathrm{~g}$ of dry silica sand were poured into the PVC cylinders to obtain a relative density of $50 \%$. Second, $75 \mathrm{~mL}$ (i.e., one pore volume) of the optimum grout solution, obtained from the test-tube experiments, were poured into the PVC cylinders from the top. The curing time of the PVC cylinder tests was determined by observing the precipitation tests. After the curing time, the treated specimens were removed from the PVC cylinders. The surface of the treated samples was flattened before the UCS tests were conducted. Two tests were performed for each condition to check the reproducibility. The UCS tests were conducted under wet conditions to avoid any unexpected precipitation that may occur when samples are intentionally dried out.

The acid leaching method was used to evaluate the amount of precipitated calcite (Yasuhara et al., 2011, 2012; Neupane et al., 2013). In this process, the treated sand was washed with distilled water to dissolve the salt material and then dried in an oven at a temperature of $100^{\circ} \mathrm{C}$ for $24 \mathrm{~h}$. The dried sand was weighed and washed with $0.1 \mathrm{~mol} / \mathrm{L}$ of $\mathrm{HCl}$ several times until air bubbles no longer appeared. Filter paper (pore size of $11 \mu \mathrm{m}$ ) was used to minimize the lost mass of sand during the washing process. The sand was dried again, and the final weight was taken. The dry weight lost during the acid leaching was evaluated and assumed to be the weight of the precipitated carbonate. The reaction taking place is expressed by Eq. 6 .

$$
\mathrm{CaCO}_{3}+2 \mathrm{HCl} \rightarrow \mathrm{CaCl}_{2}+\mathrm{CO}_{2}+\mathrm{H}_{2} \mathrm{O}
$$

TABLE 3 | Experimental conditions for evaluation of acid leaching test results.

\begin{tabular}{lccccc}
\hline $\begin{array}{l}\text { Sample } \\
\text { name (-) }\end{array}$ & $\begin{array}{c}\text { Mass of } \\
\mathbf{C a C O}_{3}(\mathbf{g})\end{array}$ & $\begin{array}{c}\text { Mass of } \\
\text { sand }(\mathbf{g})\end{array}$ & $\begin{array}{c}\text { Total } \\
\text { mass }(\mathbf{g})\end{array}$ & $\begin{array}{c}\text { Lost } \\
\text { mass } \\
\mathbf{( g )}\end{array}$ & $\begin{array}{c}\text { Percentage } \\
\text { error (\%) }\end{array}$ \\
\hline Cal1 & 0.5 & 49.5 & 50 & 0.52 & 4.0 \\
Cal2 & 1.0 & 49.0 & 50 & 1.01 & 1.0 \\
Cal3 & 1.5 & 48.5 & 50 & 1.47 & 2.0 \\
Cal4 & 2.0 & 48.0 & 50 & 2.02 & 1.0 \\
\hline
\end{tabular}

Cal5 
Similar tests were conducted to eliminate any errors that might occur due to the loss of sand during washing. The experimental conditions are shown in Table 3. Various masses of $\mathrm{CaCO}_{3}$ were also evaluated under the same conditions; refer to Table 3 . The relation between the mass of $\mathrm{CaCO}_{3}$ and the weight lost during the acid leaching is shown in Figure 2. The average percentage error was calculated to be $1.8 \%$. The percentage error is the ratio of the difference between the mass of $\mathrm{CaCO}_{3}$ and the lost mass. The minimum percentage error indicates that the acid leaching method was reasonable.

\section{RESULTS AND DISCUSSION}

The precipitation ratios of various combinations of $\mathrm{CaCl}_{2}-\mathrm{MgCl}_{2}$ with $0.5 \mathrm{~mol} / \mathrm{L}$ urea and $1.0 \mathrm{~g} / \mathrm{L}$ urease for several curing times were evaluated. Precipitation approached the steady-state condition after 5 days (Figure 3A). A summary of the precipitation ratios after 5 days of curing is shown in Figure 3B. As is apparent in the figure, the combinations that contain magnesium of 10 , 20 , and $30 \%$ have higher precipitation ratios than those without

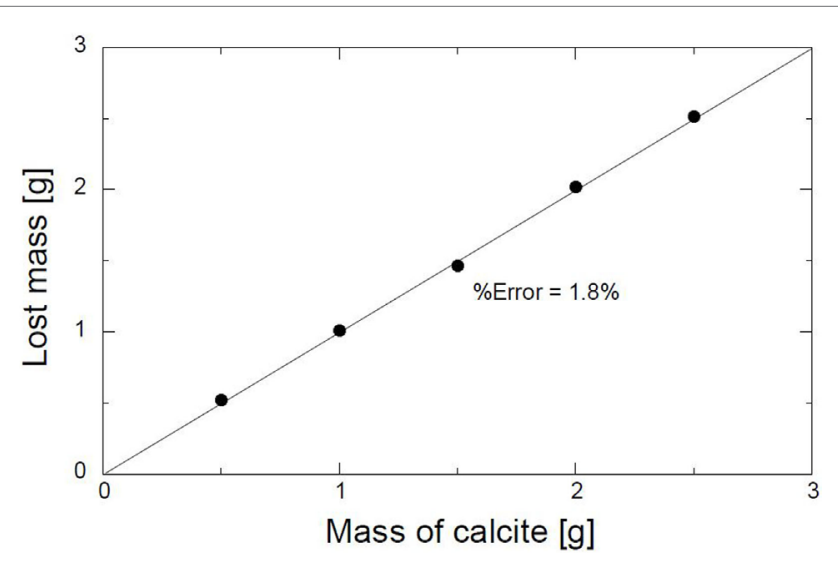

FIGURE 2 | Evaluation curve for acid leaching method of calcite quantification. magnesium. The maximum precipitation ratio without magnesium was roughly $70 \%$. The precipitation ratio increased rapidly and approached the maximum, i.e., $90 \%$, when 10 and $20 \%$ of magnesium were used. Subsequently, it decreased gradually as the magnesium ratios increased even further. It is shown that the substitution of a small amount of magnesium brings about a significant improvement in the precipitation ratio. The improvement may be due to the $\mathrm{Mg}^{2+}$ ions employed in the reaction. The presence of $\mathrm{Mg}^{2+}$ ions may promote the formation of aragonite, with a specific gravity higher than calcite (Oomori and Kitano, 1985; Boyd, 2012). Aragonite with Mohr hardness stronger than calcite can form in the presence of magnesium ions and $\mathrm{pH}<11$ (Tai and Chen, 1998). By contrast, the substitution of $40-80 \%$ magnesium causes a gradual decrease in the precipitation ratio, resulting in a reduction in the amount of carbonate precipitated.

The results of $\mathrm{pH}$ measurements are shown in Figure 4. All the measured $\mathrm{pH}$ levels increased rapidly after $1 \mathrm{~h}$. For the $\mathrm{C} 0$, the $\mathrm{pH}$ decreased gradually after $1 \mathrm{~h}$ and then approached the steady state after $3 \mathrm{~h}$. In C1, C2, and C3, the decrease in $\mathrm{pH}$ started after $2 \mathrm{~h}$ and approached constant values after $8 \mathrm{~h}$. In $\mathrm{C} 4$ and $\mathrm{C} 5$, the $\mathrm{pH}$ decreased after $4 \mathrm{~h}$. The increase in elapsed time indicates that the magnesium should influence the reaction time - the presence of the $\mathrm{Mg}^{2+}$ ions delays the reaction. The magnesium could be used as the delaying agent in calcite precipitation. In the $\mathrm{C} 0, \mathrm{CO}_{3}^{2-}$ ions directly bind with $\mathrm{Ca}^{2+}$ ions. As the magnesium was substituted, the $\mathrm{CO}_{3}^{2-}$ ions were likely to have bound with the $\mathrm{Ca}^{2+}$ and $\mathrm{Mg}^{2+}$ ions, which caused a delay in the calcite formation.

The addition of magnesium also affected the shape of the precipitated materials. XRD and SEM analyses were conducted to evaluate the effect of magnesium. The XRD results in Figure 5 show the impact of magnesium on the crystalline material. The main material was calcite. The substitution of magnesium decreased the intensity of the calcite peak and promoted the aragonite peaks. As $10 \%$ of magnesium was substituted, the intensity of the primary $(2 \theta=29.75)$ and the secondary $(2 \theta=47.54)$ peaks of calcite decreased significantly. Subsequently, the main peak of calcite $(2 \theta=29.75)$ decreased gradually as the magnesium ratio increased even further. The aragonite peaks are clearly shown when the substitution of more than $20 \%$ magnesium was conducted. Referring
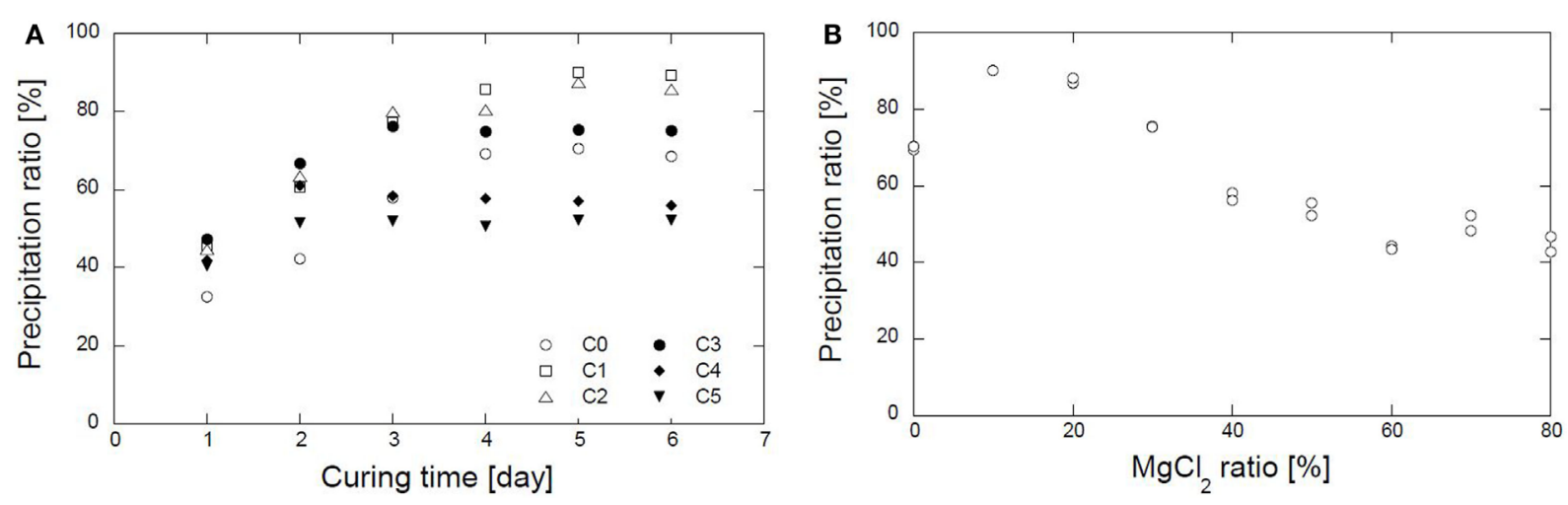

FIGURE 3 | Test-tube experiment results. (A). Precipitation ratio results in several curing time. (B) Relation between magnesium ratio and carbonate precipitation ratio. 


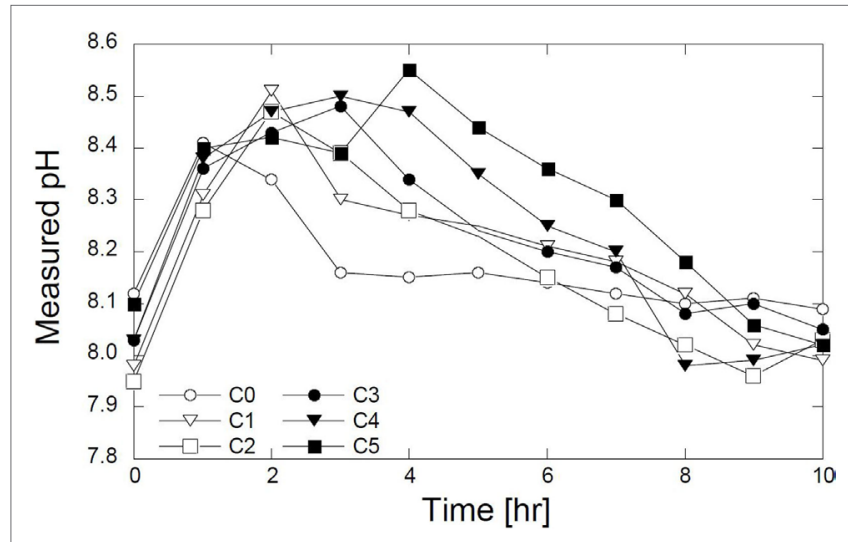

FIGURE 4 | Evolution of pH with time. to the Debye-Scherrer equation, the crystal size could be examined from the relationship between the intensity and the deviation angle from the XRD results, given by Eq. 7 (Monshi, 2012).

$$
D=\frac{\mathrm{K} \lambda}{\beta \cos \theta}
$$

$D$ is the crystal size in nanometer $(\mathrm{nm}), \lambda$ is the $\mathrm{X}$-ray wavelength, $\beta$ is the full width at half maximum (FWHM) in radians, and $K$ is a constant related to the crystallite shape, generally taken as 0.89 for spherical crystals with cubic unit cells (Monshi, 2012). The value for $\beta$ in the $2 \theta$ axis of the diffraction profile must be in radians. The effect of the substitution of magnesium on the size of the crystal material is shown in Figure 6 . The additional magnesium caused a gradual decrease in the crystal size as the magnesium ratio further increased. The substitution of 10 and
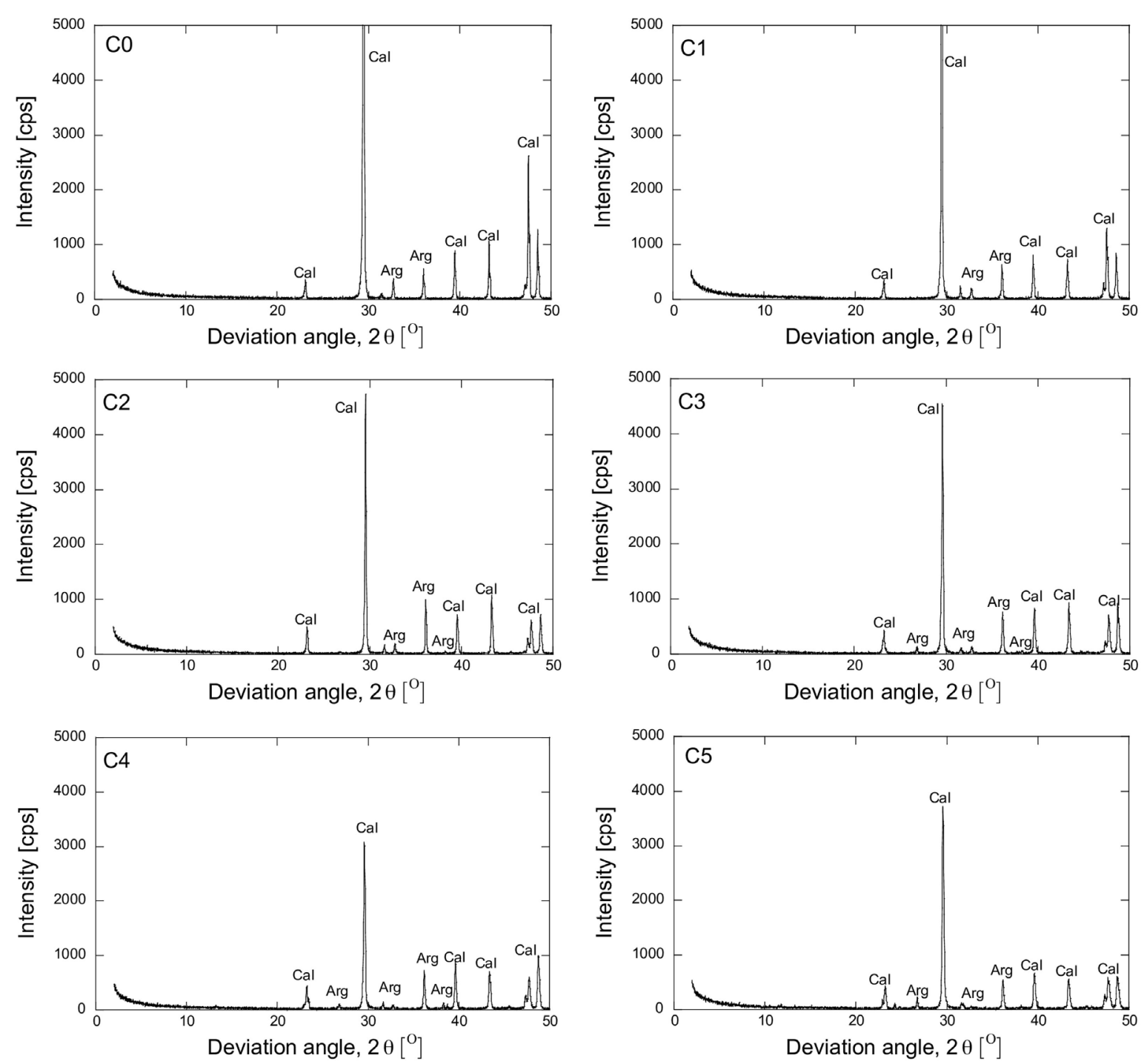

FIGURE 5 | X-ray diffraction results of precipitated material. 
$20 \%$ of magnesium reduced the crystal size to $14 \%$ of the initial size, while the substitution of $50 \%$ magnesium reduced the crystal size to half of the initial size.

The evolution of the crystal shapes obtained from the SEM analysis is shown in Figure 7. The $\mathrm{C} 0$ is the crystal structure image of calcite without the precipitation of magnesium. In such a case, the carbonation process may cause the formation of rhombohedral calcite. The substitution of magnesium modified the structure of the crystal. The rhombohedral pattern of the calcite could be observed until the additional of $20 \%$ magnesium (i.e., C2). The substitutions of magnesium decreased the amount

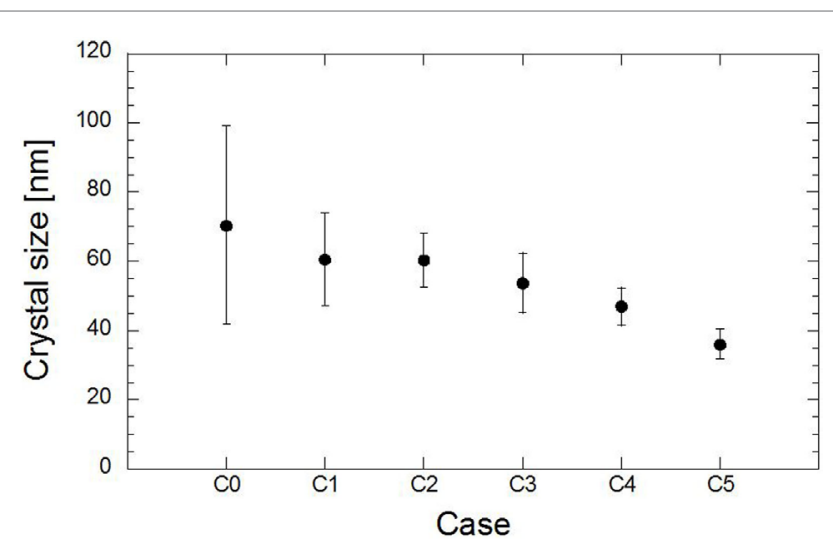

FIGURE 6 | Effect of magnesium on evolution of crystal size. of $\mathrm{Ca}^{2+}$ ions. The lower concentration of $\mathrm{Ca}^{2+}$ ions promoted the amorphous structure of the precipitated calcite minerals.

The relation between the content of the precipitated carbonate and UCS is depicted in Figure 8. The maximum UCS of $0.6 \mathrm{MPa}$ was obtained from the treated sample containing $8 \%$ precipitated carbonate. In comparison to the previous study, which addressed calcite precipitation without magnesium (Whiffin et al., 2007), the strength obtained in this study was roughly $40 \%$ higher for the same carbonate content. Cheng et al. (2013) obtained the UCS up to $0.8 \mathrm{MPa}$ from the $9 \%$ precipitated content. A similar trend to that seen in the previous study was obtained. The existence

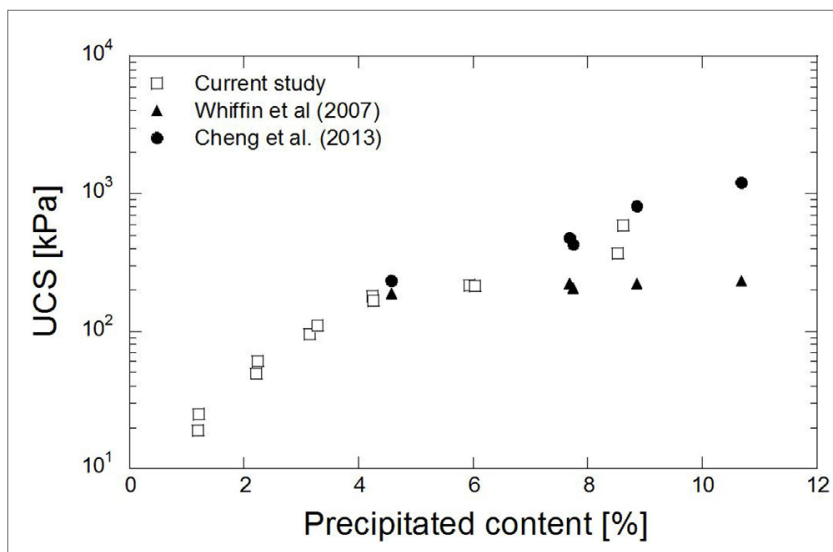

FIGURE 8 | Relationship between precipitated carbonate content and UCS tests.
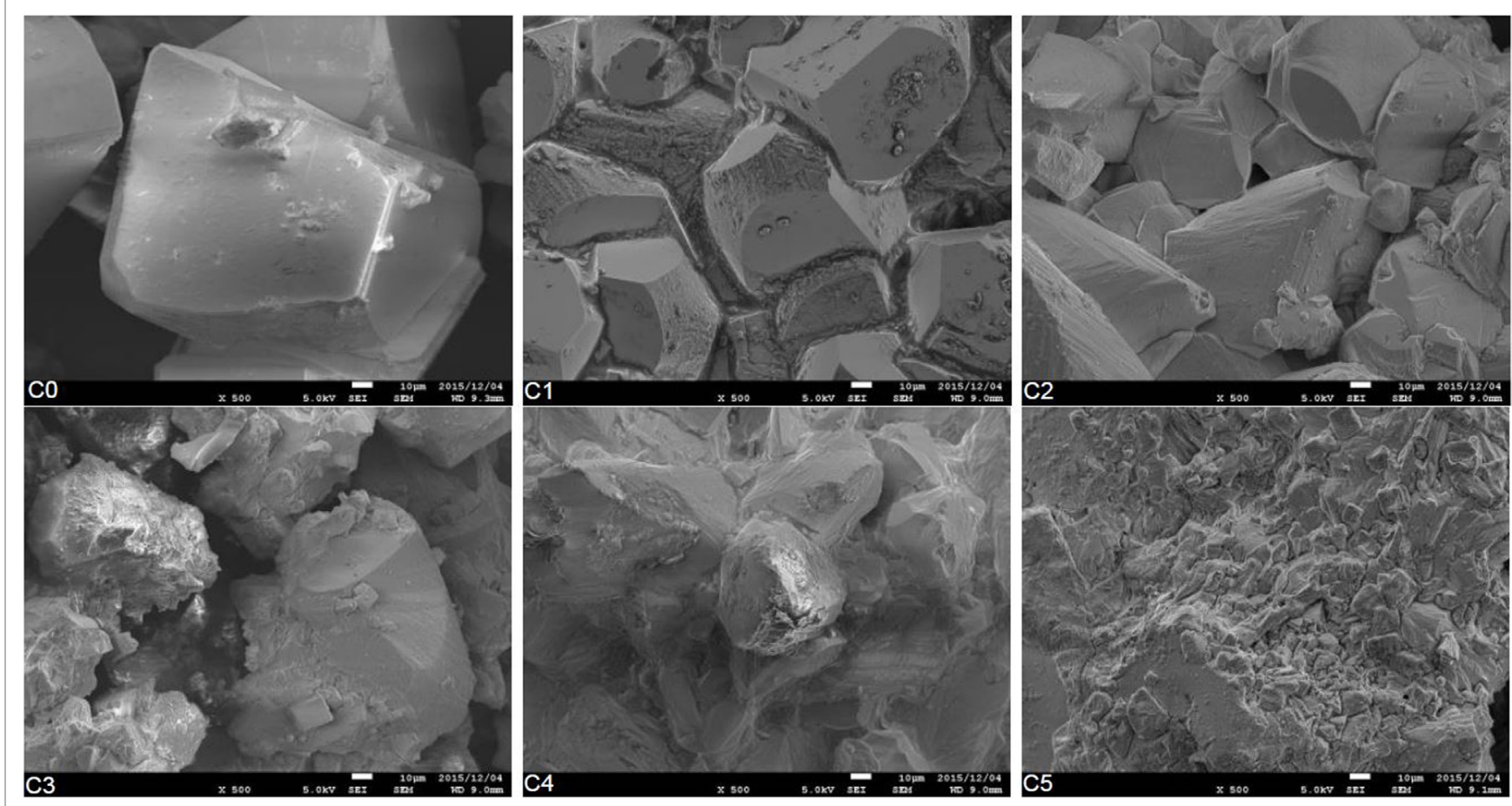

FIGURE 7 | The evolution of crystal shape as the effect of the substitution of magnesium. 
of aragonite may contribute to the increase in strength of the treated sand. Aragonite is a more compact structure of carbonate groups. The structure and the size of carbonate may influence the strength of the treated sand. The presence of agglomeration crystals in the precipitated materials, as observed in the SEM images, may increase the adhesion of the treated sand. The precipitated carbonate in sandy soil may cause the formation of a coating over the sand grains and bridges between them and bring about the binding of the sand particles. The UCS increased gradually as the precipitated content further increased. It was possible to control the UCS of the treated specimens by adjusting the amount of precipitated materials.

\section{CONCLUSION}

The efficacy of EMCP as a soil-improvement technique was evaluated. Purified urease was utilized to bio-catalyze the hydrolysis of urea to precipitate as carbonate. In this work, magnesium was newly added to optimize the rate and the amount of carbonate precipitation. In particular, the effects of magnesium chloride on the precipitated materials were examined. XRD and SEM analyses were also conducted to analyze and to examine the mineralogy composition and the microstructures of the precipitated materials.

Magnesium increased the precipitation ratio of carbonate up to $90 \%$ with the urease concentration of $1.0 \mathrm{~g} / \mathrm{L}$, and was able to be used as a delaying agent for the carbonate precipitation. The presence of magnesium changed the shape and the size of the precipitated crystals and may have resulted in the aragonite together with calcite. The presence of $\mathrm{Mg}^{2+}$ ions reduced the size of the precipitated crystals. The agglomeration of carbonate was generated by the substitution of a small amount of magnesium. UCS tests on the treated specimens revealed that precipitated carbonate was capable of noticeably modifying the mechanical properties of the soil. Relatively higher strength was obtained in this study - the presence of aragonite, induced by the substituted magnesium, improved the UCS of the treated specimens. The relation between the UCS of the treated sand and the amount of precipitated materials indicated that the strength could be controlled by the mass of the precipitated materials.

\section{AUTHOR CONTRIBUTIONS}

HP has conducted all the experiments. HY has supervised this work and suggested how to conduct the experiments. NK has suggested how to proceed this work and partly conducted the experiments. DN has suggested how to proceed this work and partly conducted the experiments. CL has suggested how to proceed this work and partly analyzed the data.

\section{ACKNOWLEDGMENTS}

This work has been partly supported by a research grant from the Penta-Ocean Constructions Co. Ltd. Their support is gratefully acknowledged.

\section{REFERENCES}

Akiyama, M., and Kawasaki, S. (2012). Microbially mediated sand solidification using calcium phosphate compounds. Eng. Geol. 137-138, 29-39. doi:10.1016/j. enggeo.2012.03.016

Al-Thawadi, S. M. (2011). Ureolytic bacteria and calcium carbonate formation as a mechanism of strength enhancement of sand. J. Adv. Sci. Eng. Res. 1, 98-114.

Apriliani, N. F., Baqiya, M. A., and Darminto. (2012). Pengaruh penambahan larutan " $\mathrm{MgCl}_{2}$ " pada sintesis kalsium karbonat presipitat berbahan dasar batu kapur dengan metode karbonasi. Sains dan Seni ITS 1, B30-B34.

Boyd, V. H. (2012). The Effect of Calcium and Magnesium on Carbonate Mineral Precipitation During Reactive Transport in a Model Subsurface Pore Structure. Urbana: University of Illinois.

Cheng, L., Cord-Ruwisch, R., and Shahin, M. A. (2013). Cementation of sand soil by microbially induced calcite precipitation at various degrees of saturation. Can Geotech J 50, 81-90. doi:10.1139/cgj-2012-0023

De Muynck, W., Debrouwer, D., De Belie, N., and Verstraete, W. (2008). Bacterial carbonate precipitation improves the durability of cementitious materials. Cem. Concr. Res. 38, 1005-1014. doi:10.1016/j.cemconres.2008.03.005

DeJong, J. T., Mortensen, B. M., Martinez, B. C., and Nelson, D. C. (2010). Bio-mediated soil improvement. Ecol. Eng. 36, 197-210. doi:10.1016/j. ecoleng.2008.12.029

DeJong, J. T., Fritzges, M. B., and Nüsslein, K. (2006). Microbially induced cementation to control sand response to undrained shear. J. Geotech. Geoenviron. Eng. 132, 1381-1392. doi:10.1061/(ASCE)1090-0241(2006)132:11(1381)

DeJong, J. T., Soga, K., Banwart, S. A., Whalley, W. R., Ginn, T. R., Nelson, D. C., et al. (2011). Soil engineering in vivo: harnessing natural biogeochemical systems for sustainable, multi-functional engineering solutions. J. R. Soc. Interface 8, 1-15. doi:10.1098/rsif.2010.0270

Harkes, M. P., van Paassen, L. A., Booster, J. L., Whiffin, V. S., and van Loosdrecht, M. C. M. (2010). Fixation and distribution of bacterial activity in sand to induce

carbonate precipitation for ground reinforcement. Ecol. Eng. 36, 112-117. doi:10.1016/j.ecoleng.2009.01.004

Ivanov, V., and Chu, J. (2008). Applications of microorganisms to geotechnical engineering for bioclogging and biocementation of soil in situ. Rev. Environ. Sci. Biotechnol. 7, 139-153. doi:10.1007/s11157-007-9126-3

Martinez, B. C., DeJong, J. T., Ginn, T. R., Montoya, B. M., Barkouki, T. H., Hunt, C., et al. (2013). Experimental optimization of microbial-induced carbonate precipitation for soil improvement. J. Geotech. Geoenviron. Eng. 139, 587-598. doi:10.1061/(ASCE)GT.1943-5606.0000787

Monshi, A. (2012). Modified Scherrer equation to estimate more accurately nano-crystallite size using XRD. World J. Nano Sci. Eng. 02, 154-160. doi:10.4236/wjnse.2012.23020

Nemati, M., Greene, E. A., and Voordouw, G. (2005). Permeability profile modification using bacterially formed calcium carbonate: comparison with enzymic option. Process Biochem. 40, 925-933. doi:10.1016/j. procbio.2004.02.019

Neupane, D., Yasuhara, H., Kinoshita, N., and Unno, T. (2013). Applicability of enzymatic calcium carbonate precipitation as a soil-strengthening technique. Geotech. Geoenviron. Eng. ASCE 139, 2201-2211. doi:10.1061/(ASCE) GT.1943-5606.0000959

Neupane, D., Yasuhara, H., Kinoshita, N., and Ando, Y. (2015). Distribution of mineralized carbonate and its quantification method in enzyme mediated calcite precipitation technique. Soil Found. 55, 447-457. doi:10.1016/j. sandf.2015.02.018

Oomori, T., and Kitano, Y. (1985). Catalytic effect of magnesium ions on polymorphic crystallization of calcium carbonate. Bull. Coll. Sci. Univ. Ryukyus 39, $57-62$.

Putra, H., Yasuhara, H., Kinoshita, N., and Neupane, D. (2015). “Optimization of calcite precipitation as a soil improvement technique," in Proceedings of the 2nd Makassar International Conference on Civil Engineering (Makassar: Civil Engineering Department, Hasanuddin University), 9-14. doi:10.13140/ RG.2.1.1979.1848 
Tai, C. Y., and Chen, F. B. (1998). Polymorphism of CaCO3, precipitated in a constant-composition environment. AIChE J.44, 1790-1798. doi:10.1002/ aic.690440810

van Paassen, L. A., Harkes, M. P., Van Zwieten, G. A., Van Der Zon, W. H., Van Der Star, W. R. L., and Van Loosdrecht, M. C. M. (2009). "Scale up of BioGrout: a biological ground reinforcement method," in Proceedings of the 17th International Conference on Soil Mechanics and Geotechnical Engineering: The Academia and Practice of Geotechnical Engineering, Vol. 3 (Alexandria: IOS Press), 2328-2333.

van Paassen, L. A., Ghose, R., Van der Linden, T. J. M., Van der Star, W. R. L., and Van Loosdrecht, M. C. M. (2010). Quantifying biomediated ground improvement by ureolysis: large-scale biogrout experiment. J. Geotech. Geoenviron. Eng. 136, 1721-1728. doi:10.1061/(ASCE)GT.1943-5606.0000382

Whiffin, V.S. (2004). Microbial CaCO3 Precipitation for the Production of Biocement. Ph.D. thesis, Murdoch University, Perth, Victoria, 1-162.

Whiffin, V. S., van Paassen, L. A., and Harkes, M. P. (2007). Microbial carbonate precipitation as a soil improvement technique. Geomicrobiol. J. 24, 417-423. doi:10.1080/01490450701436505
Yasuhara, H., Neupane, D., Hayashi, K., and Okamura, M. (2012). Experiments and predictions of physical properties of sand cemented by enzymatically-induced carbonate precipitation. Soil Found. 52, 539-549. doi:10.1016/j. sandf.2012.05.011

Yasuhara, H., Hayashi, K., and Okamura, M. (2011). Evolution in mechanical and hydraulic properties of calcite-cemented sand mediated by biocatalyst. Geo Front. 2011, 3984-3992. doi:10.1061/41165(397)407

Conflict of Interest Statement: The authors declare that the research was conducted in the absence of any commercial or financial relationships that could be construed as a potential conflict of interest.

Copyright (C) 2016 Putra, Yasuhara, Kinoshita, Neupane, and Lu. This is an open-access article distributed under the terms of the Creative Commons Attribution License (CC BY). The use, distribution or reproduction in other forums is permitted, provided the original author(s) or licensor are credited and that the original publication in this journal is cited, in accordance with accepted academic practice. No use, distribution or reproduction is permitted which does not comply with these terms. 